\title{
Key drivers controlling stable isotope variations in daily precipitation of Costa Rica: Caribbean Sea versus Eastern Pacific Ocean moisture
} \section{sources}

\author{
R. Sánchez-Murillo a, *, C. Birkel ${ }^{\text {b, c }}$, K. Welsh ${ }^{\text {d, e }}$, G. Esquivel-Hernández a \\ J. Corrales-Salazar ${ }^{\text {a }}$, J. Boll ${ }^{\text {f }}$, E. Brooks ${ }^{\text {d, O. Ooupsard }}{ }^{\text {e,g }}$, O. Sáenz-Rosales ${ }^{\text {a }}$, I. Katchan ${ }^{\text {h }}$, \\ R. Arce-Mesén ${ }^{\text {b }}$, C. Soulsby ${ }^{\mathrm{c}}$, L.J. Araguás-Araguás ${ }^{\mathrm{i}}$ \\ a Stable Isotope Research Group, National University of Costa Rica, Heredia, 86-3000, Costa Rica \\ ${ }^{\mathrm{b}}$ Escuela de Geografia, Universidad de Costa Rica, 11501-2060, Costa Rica \\ ${ }^{\mathrm{c}}$ Northern Rivers Institute, University of Aberdeen, Aberdeen, AB24 3UF, Scotland \\ d University of Idaho, Moscow, ID, 83844-3006, USA \\ e Centro Agronómico Tropical de Investigación y Enseñanza, Turrialba, 30501, Costa Rica \\ ${ }^{\mathrm{f}}$ Washington State University, Pullman, WA, 99164, USA \\ ${ }^{g}$ CIRAD, UMR Ecologie Fonctionelle and Biogéochimie des Sols et des Agro-écosystèmes, Montpellier, 34060, France \\ h Centro Nacional de Alta Tecnología, San José, 1174-1200, Costa Rica \\ ${ }^{\mathrm{i}}$ Isotope Hydrology Section, International Atomic Energy Agency, Vienna International Centre, PO Box 100, 1400 Vienna, Austria
}

\section{A R T I C L E I N F O}

\section{Article history:}

Received 28 October 2014

Received in revised form

7 August 2015

Accepted 24 August 2015

Available online 11 September 2015

\section{Keywords:}

Costa Rica

Stable isotopes

Precipitation

Air mass back trajectories

Sounding profiles

\begin{abstract}
A B S T R A C T
Costa Rica is located on the Central American Isthmus, which receives moisture inputs directly from the Caribbean Sea and the Eastern Pacific Ocean. This location includes unique mountainous and lowland microclimates, but only limited knowledge exists about the impact of relief and regional atmospheric circulation patterns on precipitation origin, transport, and isotopic composition. Therefore, the main scope of this project is to identify the key drivers controlling stable isotope variations in daily-scale precipitation of Costa Rica. The monitoring sites comprise three strategic locations across Costa Rica: Heredia (Central Valley), Turrialba (Caribbean slope), and Caño Seco (South Pacific slope). Sporadic dry season rain is mostly related to isolated enriched events ranging from $-5.8 \%$ to $-0.9 \%$ o $\delta^{18} \mathrm{O}$. By midMay, the Intertropical Convergence Zone reaches Costa Rica resulting in a notable depletion in isotope ratios (up to $-18.5 \% \delta^{18} \mathrm{O}$ ). HYSPLIT air mass back trajectories indicate the strong influence on the origin and transport of precipitation of three main moisture transport mechanisms, the Caribbean Low Level Jet, the Colombian Low Level Jet, and localized convection events. Multiple linear regression models constructed based on Random Forests of surface meteorological information and atmospheric sounding profiles suggest that lifted condensation level and surface relative humidity are the main factors controlling isotopic variations. These findings diverge from the recognized 'amount effect' in monthly composite samples across the tropics. Understanding of stable isotope dynamics in tropical precipitation can be used to a) enhance groundwater modeling efforts in ungauged basins where scarcity of long-term monitoring data drastically limit current and future water resources management, b) improve the reconstruction of paleoclimatic records in the Central American land bridge, c) calibrate and validate regional circulation models.
\end{abstract}

(c) 2015 Elsevier Ltd. All rights reserved.

\footnotetext{
Notation list: $\delta^{2} \mathrm{H}$, deuterium isotope (\%o); $\delta^{18} \mathrm{O}$, oxygen-18 isotope (\%o); CAPE, convection available potential energy (J/Kg); CAPEv, convection available potential energy using virtual temperature (J/Kg); CIN, convection inhibition (J/kg); CLLJ, Caribbean low level jet; CHOCO, Colombian low level jet; D-xs, deuterium excess (\%o); GNIP, global network of isotopes in precipitation; GWML, global meteoric water line; HYSPLIT, hybrid single particle Lagrangian integrated trajectory model; IAEA, international atomic energy agency; ITCZ, intertropical convergence zone; LCL, lifted condensation level (m); LCLp, lifted condensation level pressure (hPa); LCLt, lifted condensation level temperature $\left({ }^{\circ} \mathrm{C}\right)$; LFC, level of free convection $(\mathrm{m})$; LFCv, level of free convection using virtual temperature $(\mathrm{m})$; LMWL, local meteoric water line; MR, mean layer mixing ratio; MLR, multiple linear regression; P, daily precipitation $(\mathrm{mm})$; PW, precipitable water $(\mathrm{mm})$; RH, mean daily relative humidity $(\%)$; $\mathrm{T}$, mean daily air temperature $\left({ }^{\circ} \mathrm{C}\right)$; VSMOW, vienna standard mean ocean water; WMO, world meteorological organization; WS, mean daily wind speed (m/s).

* Corresponding author. Universidad Nacional de Costa Rica Campus Omar Dengo, Heredia, P.O. Box: 86 3000, Costa Rica.

E-mail address: ricardo.sanchez.murillo@una.cr (R. Sánchez-Murillo).
} 


\section{Introduction}

Tropical regions cover approximately 50\% of Earth's landmass and are home to three-quarters of the world's population. During the last decade, the scientific community, environmental institutions, governments, and communities have increased their awareness of the importance of current tropical climate variability based on the premise that changes in regional and global circulation patterns may lead to intensification of extreme events (i.e. floods or severe droughts). Past climate records of tree rings, speleothems, and coral reef formations in tropical environments offer a unique opportunity to a) examine previous abrupt climate changes and $b$ ) elucidate the hydrological responses to thermal and precipitation anomalies.

The use of stable isotopes of water, both $\delta^{2} \mathrm{H}$ and $\delta^{18} \mathrm{O}$ has provided novel insights in hydrological studies, ecological applications, understanding climate variability, and reconstructing paleoclimate (Lawrence et al., 2004; Johnson and Ingram, 2004; Risi et al., 2008; Lachniet, 2009a; Sturm et al., 2010; Tremoy et al., 2012; Moerman et al., 2013; Tremoy et al., 2014; Okazaki et al., 2015). Recently, the development of inexpensive instrumentation based on laser spectroscopy has enhanced our ability to achieve greater temporal and spatial resolution of isotopic data (Berden et al., 2000; Wen et al., 2008; Gupta et al., 2009; Munksgaard et al., 2012, 2015; Good et al., 2014; Munksgaard et al., 2015) and is greatly helping in development of new research avenues to study the atmospheric water cycle (e.g. ${ }^{17}$ O-excess; Berman et al., 2013). In particular, collection and analyses techniques of these naturally occurring tracers have shown to be useful in elucidating atmospheric moisture sources and their implications for the hydrological cycle (Araguas-Araguas et al., 2000; Bowen and Revenaugh, 2003; Aggarwal et al., 2012; Risi et al., 2013; Soderberg et al., 2013).

The global relationship between $\delta^{2} \mathrm{H}$ and $\delta^{18} \mathrm{O}$ in natural meteoric waters recognized by Craig (1961) and later defined as the GMWL $\left(\delta^{2} \mathrm{H}=8 \cdot \delta^{18} \mathrm{O}+10\right)$ serves as a foundational reference to determine regional and local deviations (LMWL) from equilibrium processes and the potential origin of the water vapor. Other factors, such as the trajectory of air masses, latitude, altitude, precipitation amount, and distance from oceans, may also affect the spatial and temporal variations of $\delta^{2} \mathrm{H}$ and $\delta^{18} \mathrm{O}$ ratios in precipitation (Rozanski et al., 1982). Water losses due to evaporation, the incorporation of recycled atmospheric moisture, and mixing between isotopically-distinct reservoirs leave a unique water fingerprint that can be used to understand rainfall-runoff processes (Birkel et al., 2012), complex water flow paths (McGlynn et al., 2002), groundwater to surface water connectivity (Tetzlaff and Soulsby, 2008; Speed et al., 2010; Wassenaar et al., 2011), baseflow recession analysis (Sánchez-Murillo et al., 2015) and isotope-based paleoclimate-reconstructions (Moerman et al., 2013). Light stable isotope compositions of tropical meteoric waters have proven to be an important indicator of modern climate variability (AraguásAraguás et al., 1998; Vuille et al., 2000a,b; 2003; Cobb et al., 2007; Lachniet, 2009b; Lachniet and Paterson, 2009; Ishizaki et al., 2012; Moerman et al., 2013). In particular, $\delta^{18}$ O values have provided novel insights into El Niño/Southern Oscillation dynamics (Vuille and Werner, 2005; Ichinayagi and Yamanaka, 2005; Lachniet et al., 2007; Panarello and Dapeña, 2009).

Despite these advances to understand stable isotope precipitation dynamics in the tropics, a consensus exists regarding the urgent need for long-term monitoring networks, particularly in mountainous regions such as the Central America Continental Divide where orographic effects, local moisture recycling, canopy interception, intense evapotranspiration combined with complex microclimates may play an important role in influencing isotopic ratios (Lachniet and Paterson, 2009). Furthermore, recent studies have demonstrated that variations in the stable isotope composition of precipitation even occur during storm events (Celle-Jeanton et al., 2004; Coplen et al., 2008; Barras and Simmonds, 2009; Munskgaard et al., 2012), emphasizing the relevance of eventbased and daily sampling. A physical understanding of the key

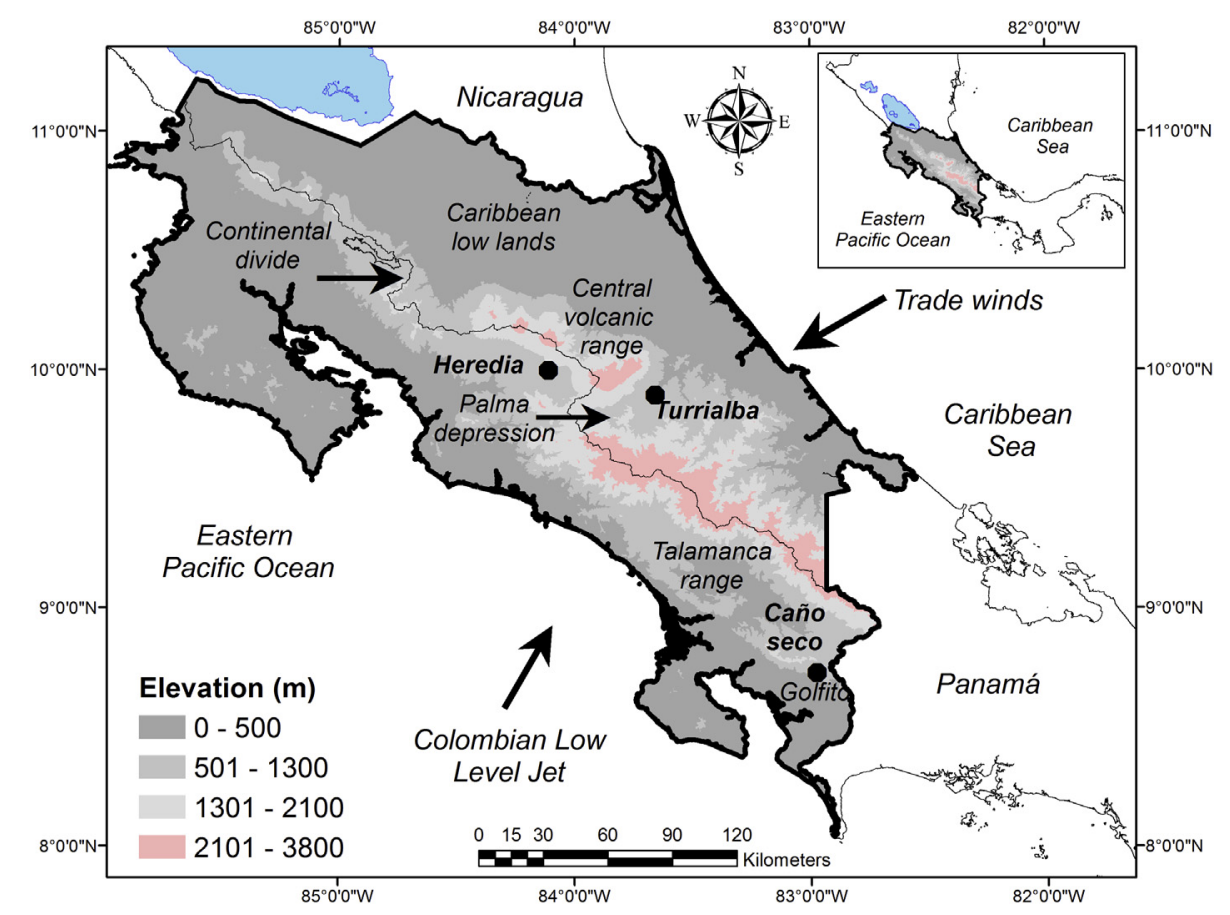

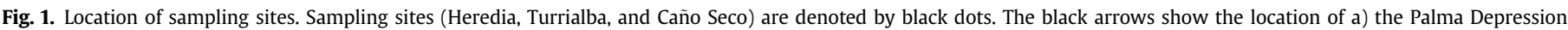

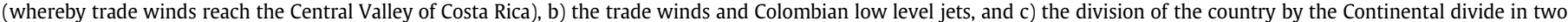

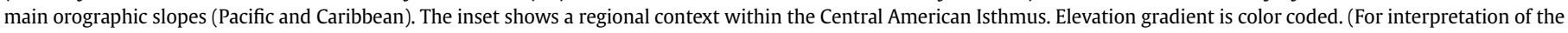
references to colour in this figure legend, the reader is referred to the web version of this article.) 
Table 1

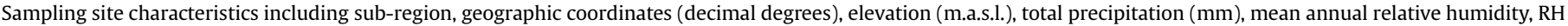
$(\%)$, mean annual temperature $\left({ }^{\circ} \mathrm{C}\right)$, and number of rainfall events $(\mathrm{N})$ collected during 2013.

\begin{tabular}{|c|c|c|c|c|c|c|c|c|}
\hline Site & Sub-region & Latitude (dec.deg) & Longitude (dec.deg) & Elevation (m.a.s.l.) & Total precipitation (mm) & Mean annual RH (\%) & Mean annual temperature $\left({ }^{\circ} \mathrm{C}\right)$ & $\mathrm{N}$ \\
\hline Heredia & Central valley & 10.0004 & -84.1091 & 1173 & 2508 & 79.1 & 20.1 & 49 \\
\hline Turrialba & Caribbean slope & 9.8970 & -83.6570 & 1020 & 2006 & 84.9 & 19.6 & 46 \\
\hline Caño Seco & S. Pacific slope & 8.7304 & -82.9742 & 1037 & 2663 & 95.3 & 19.9 & 73 \\
\hline
\end{tabular}

factors controlling stable isotope ratios of meteoric waters in the tropics will strengthen understanding of precipitation origin and transport (e.g. calibration and validation of Global and Regional Circulation Models), and provide contemporary isotopic data to enhance paleo-reconstructions and sustainable water resources management.

\subsection{Isotopic variations in tropical meteoric waters}

In temperate climates, stable isotope variations in meteoric waters have been successfully explained by the seasonal air temperature fluctuation, a relationship known as the "temperature effect' (Dansgaard, 1964; Rozanski et al., 1993; Araguás-Araguás et al., 2000; Kurita et al., 2009; Wassenaar et al., 2011; Sánchez-Murillo et al., 2013). However, in tropical regions where temperature variability is muted, the isotopic ratios of meteoric waters only
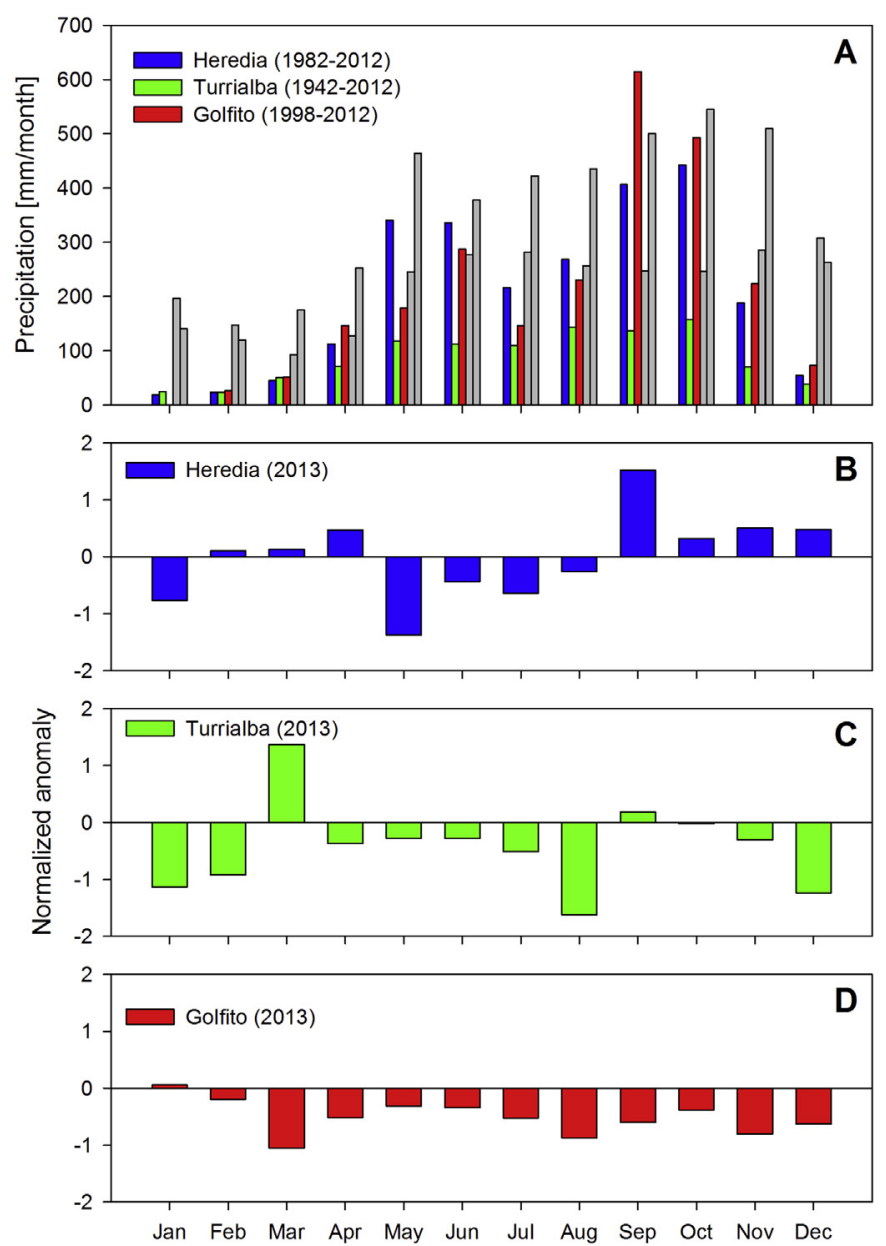

Fig. 2. Time series of monthly long-term precipitation means (A) and comparison of monthly standardized anomalies for 2013 for three locations Heredia (B), Turrialba (B), and Golfito (D) (20 km southwest of Caño Seco). Baseline precipitation periods are: Heredia (1982-2012), Turrialba (1942-2012), and Golfito (1998-2012). Normalized anomaly equals anomaly/standard deviation of the normal period at each site. exhibit a weak correlation with surface air temperature. Instead for these regions, several studies have reported a negative correlation between precipitation amount and isotope values, a relationship commonly recognized as the 'amount effect' (Dansgaard, 1964; Rozanski et al., 1993; Araguás-Araguás et al., 1998; Vimeux et al., 2005; Kurita et al., 2009; Scholl et al., 2009; Sánchez-Murillo et al., 2013). The shift from air temperature to precipitation amount controlling isotopic ratios is generally noted around $30^{\circ} \mathrm{N} /$ $S$ (Bowen, 2008). The 'amount effect' occurs as a result of rain-out processes of convective precipitation. The stronger the convective nature of a rainfall event, the greater is the total precipitation amount, and thus the lower the probability of moisture exchange during the drop travel time towards the surface (Vuille et al., 2003). While the 'amount effect' is the strongest relationship identified in the tropics, the majority of studies were based on monthlycomposite samples, such as those recorded in the Global Network of Isotopes in Precipitation (GNIP) (http://www-naweb.iaea.org/ napc/ih/IHS_resources_gnip.html) database overseen by the International Atomic Energy Agency (IAEA) and the World Meteorological Organization (WMO). This 'amount effect' appears to be stronger when examined over longer periods of time and not at shorter sampling intervals (Risi et al., 2008; Wu et al., 2015). Nevertheless, daily or event-based sampling of precipitation often does not show a strong correlation with precipitation amount (Vimeux et al., 2005; Wu et al., 2010, 2015). A vast majority of fractionation processes that may potentially influence the stable isotope composition of tropical precipitation occur along the convective vertical profile (Kurita, 2013); therefore, to further understand the key factors controlling stable isotope composition in tropical precipitation, a detailed analysis combining surface and sounding meteorological data is required.

This study examined daily isotopic variations at three strategic locations in Costa Rica for the year 2013: Heredia (Central Valley, which receives moisture inputs from both the Pacific and Caribbean), Turrialba (Caribbean Slope), and Caño Seco (South Pacific

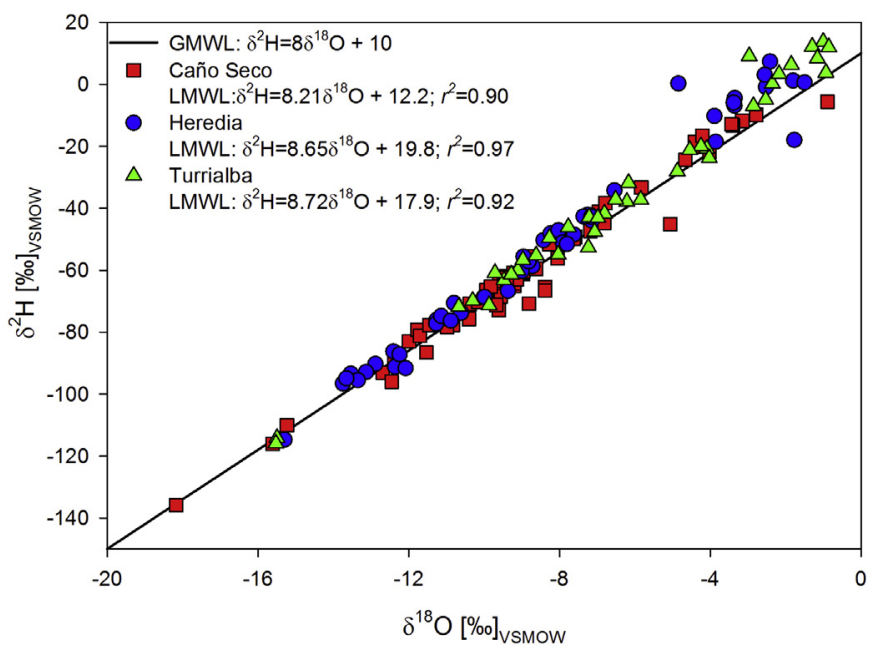

Fig. 3. LMWL constructed for the three study sites. The GMWL is shown as a reference. Note that only the equations of the LMWLs are given for clarity. 
Slope). Isotope ratios were analyzed in combination with surface and convective meteorological data and HYSPLIT air mass back trajectories to i) investigate whether key drivers of isotopic variability can be identified, and ii) determine the precipitation moisture source.

\section{Regional setting and previous isotopic studies}

Costa Rica is located on the Central American Isthmus, between $8^{\circ}$ and $12^{\circ} \mathrm{N}$ latitude, and $82^{\circ}$ and $85^{\circ} \mathrm{W}$ longitude (Fig. 1). This narrow land bridge provides unique mountainous and lowland microclimatic systems (i.e. climate characteristics controlled by the strong influence of topographic features) across the country, which receives moisture inputs from two large water masses: the eastern tropical Pacific and the Caribbean Sea warm pools (DuránQuesada et al., 2010). These microclimatic systems offer a unique opportunity to study isotopic variations in precipitation in a tropical setting where over 258 karst caves (Ulloa et al., 2011) remain basically unexplored for paleoclimate records. Four regional air circulation processes predominantly control the climate of Costa Rica: northeast trade winds (i.e. alisios), the latitudinal migration of the Intertropical Convergence Zone (ITCZ), cold continental outbreaks (i.e. northerly winds or nortes), and the seasonal influence of Caribbean cyclones (Waylen, 1996). These circulation processes produce two rainfall maxima, one in June and one in September, which are interrupted by a relative minimum between July-August known as the Mid-Summer Drought (i.e. intensification of the trade winds over the Caribbean Sea) (Magaña et al., 1999). In addition to these circulation processes, the Continental Divide (i.e. a mountainous range extending from northwest to southeast) also influences precipitation patterns across the country, dividing the territory into the Caribbean and Pacific drainage basin. Both basins exhibit distinct rainfall regimes in terms of magnitude and timing (Muñoz et al., 2002). In general, annual precipitation in Costa Rica varies from $\sim 1500 \mathrm{~mm}$ in the drier northwestern region, $\sim 2500 \mathrm{~mm}$ in the Central Valley, and up to $\sim 7000 \mathrm{~mm}$ on the Caribbean side of the Talamanca range. Temperature seasonality is low throughout the country. The mean annual temperature on the coastal lowlands is around $27^{\circ} \mathrm{C}, 20^{\circ} \mathrm{C}$ in the Central Valley at around 1100 m.a.s.l., and below $10{ }^{\circ} \mathrm{C}$ at the summits of the highest mountain range (3820 m.a.s.l.) (Sánchez-Murillo et al., 2013).

Isotopic studies conducted in meteoric waters of Costa Rica have been limited to date. Sánchez-Murillo et al. (2013) analyzed historic monthly records from GNIP and provided the first comprehensive analysis of the variations in isotopic composition of precipitation in Costa Rica. The authors defined a country weighted-LMWL of $\delta^{2} \mathrm{H}=7.6 \cdot \delta^{18} \mathrm{O}+7.40$. In particular, the authors determined an 'amount effect' of $-1.6 \% \delta^{18} \mathrm{O}$ per $100 \mathrm{~mm}$ of rain, which corresponds to a temperature effect of $-0.37 \% 0 \delta^{18} \mathrm{O} /{ }^{\circ} \mathrm{C}$. Rhodes et al. (2006a,b) and Guswa et al. (2007) conducted studies of the isotopic composition of precipitation in the Monteverde Cloud Forest Reserve, identifying that water evaporated from land is an important moisture flux during the transitional and dry seasons with dominating winds from the Caribbean. Additional studies (Lachniet and Patterson, 2002; Reynolds and Fraile, 2009; Melchiorre et al., 2009) on stable isotopes in surface waters and groundwaters did not examine the factors that influence the isotopic composition of precipitation.

\section{Materials and methods}

\subsection{Sampling sites}

A daily sampling campaign was conducted during 2013 at three
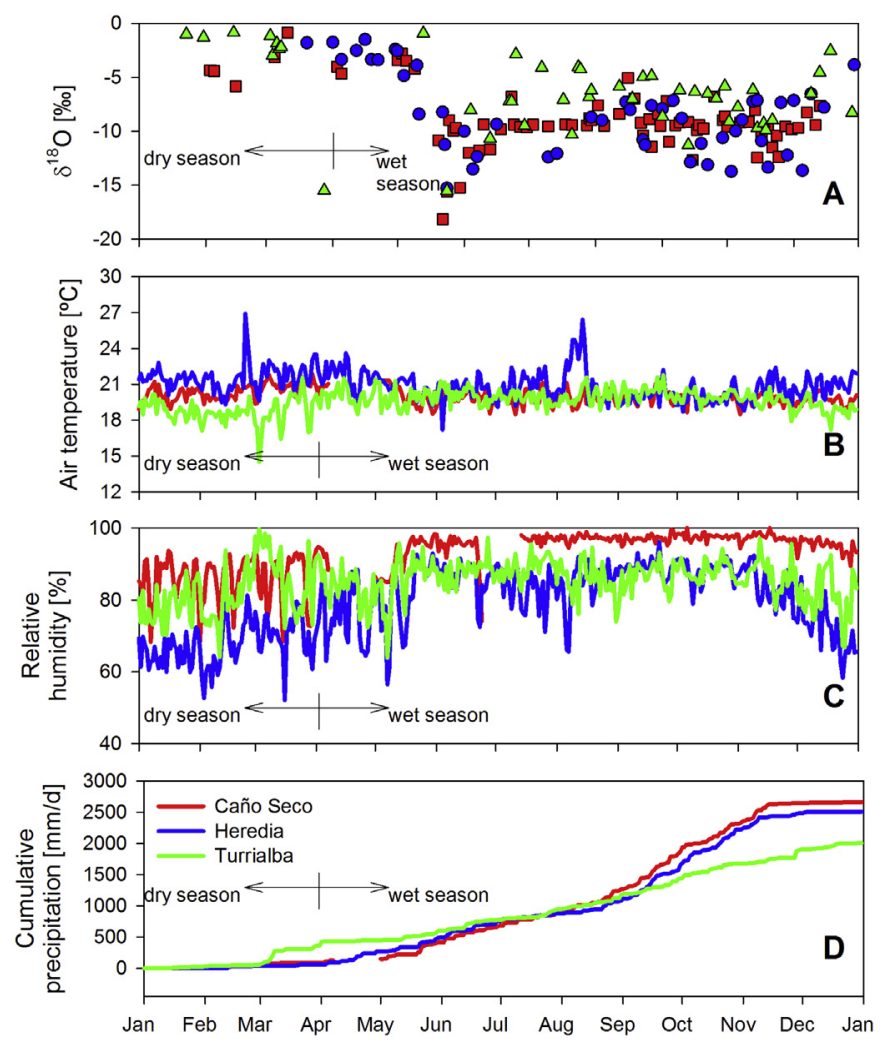

Fig. 4. Time series of (A) precipitation $\delta^{18} \mathrm{O}$ and observed surface meteorological variables, (B) air temperature, (C) relative humidity and (D) cumulative precipitation during 2013 at the three study sites Heredia (blue), Turrialba (green) and Caño Seco (red). Black arrows denote the transition from the dry season (Dec-April) to the wet season (May-Nov). (For interpretation of the references to colour in this figure legend, the reader is referred to the web version of this article.)

sites: Heredia (Central Valley), Turrialba (Caribbean slope), and Caño Seco (Pacific slope) (Fig. 1 and Table 1). Heredia is located within the Central Volcanic Range at 1173 m.a.s.l. Mean annual precipitation (period 1982-2012) is $2452 \mathrm{~mm}$ with two rainfall maxima between May-June and September-October and a clear dry season from December to April. Precipitation events in Heredia are composed of moisture transported from the Caribbean lowlands through the Palma Depression and the Pacific Ocean. Turrialba is located on the Caribbean slope at 1020 m.a.s.l. (Coffee-Flux Observatory, Aquiares station, 9 km northwest of Turrialba, GómezDelgado et al., 2011). Mean annual precipitation is $2712 \mathrm{~mm}$ (period 1942-2012). A precipitation maximum occurs between November and January due to the increasing strength of northeast trade

Table 2

Summary of seasonal $\delta^{18} \mathrm{O}(\%), \delta^{2} \mathrm{H}(\%)$, and d-excess (\%o) arithmetic means at Heredia, Turrialba and Caño Seco.

\begin{tabular}{llll}
\hline Site & $\delta^{18} \mathrm{O}(\%)$ & $\delta^{2} \mathrm{H}(\% 0)$ & $d$-excess $(\% 0)$ \\
\hline Dry season & & & \\
Heredia & -2.52 & -4.96 & 15.2 \\
Turrialba & -3.24 & -5.47 & 20.4 \\
Caño Seco & -3.90 & -19.40 & 11.8 \\
Wet season & & & \\
Heredia & -9.31 & -60.18 & 14.3 \\
Turrialba & -7.07 & -48.39 & 8.2 \\
Caño Seco & -9.42 & -65.09 & 10.2 \\
Annual & & & \\
Heredia & -8.34 & -52.29 & 14.4 \\
Turrialba & -6.20 & -39.99 & 10.6 \\
Caño Seco & -8.84 & -60.42 & 10.3 \\
\hline
\end{tabular}


R. Sánchez-Murillo et al. / Quaternary Science Reviews 131 (2016) 250-261

A

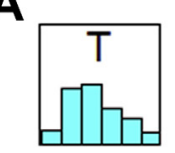

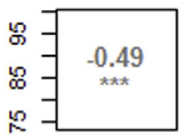

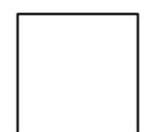

음

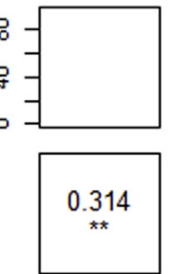

井 0.379

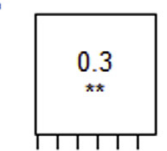

18.520 .0
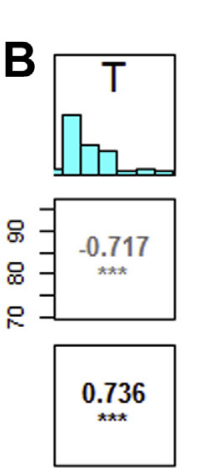

을
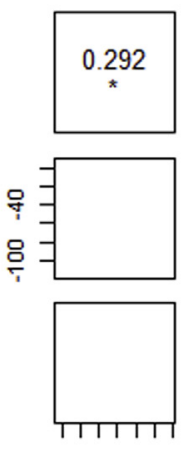

$19 \quad 22$
$75 \quad 8595$
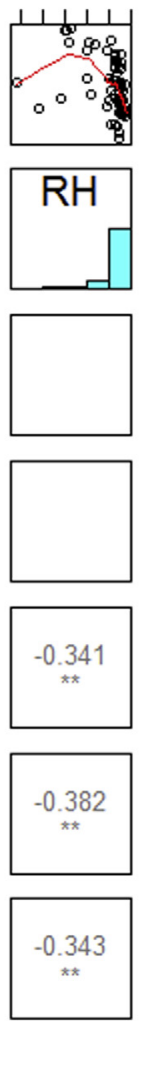

$\begin{array}{lll}70 & 80 & 90\end{array}$
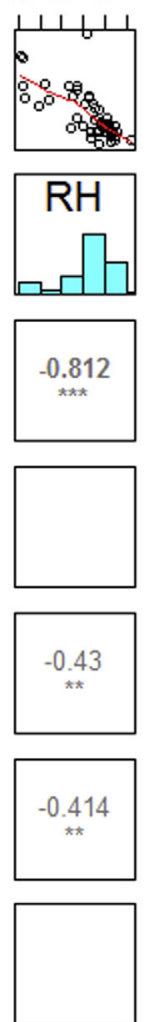
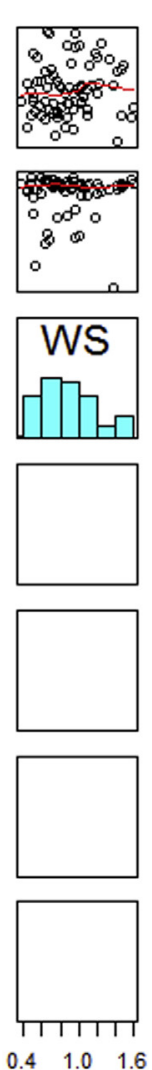

$0.4 \quad 1.0 \quad 1.6$
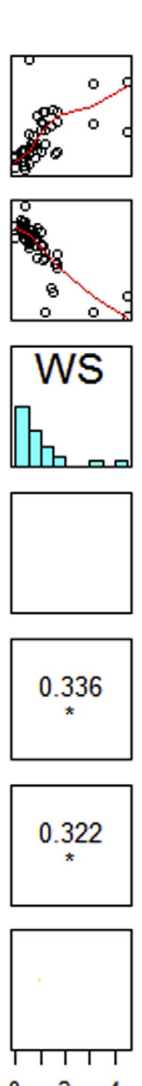
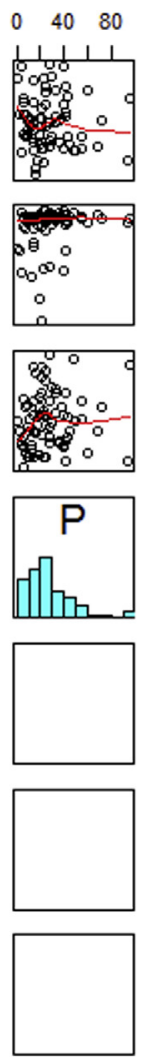

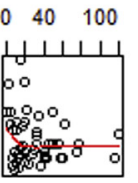
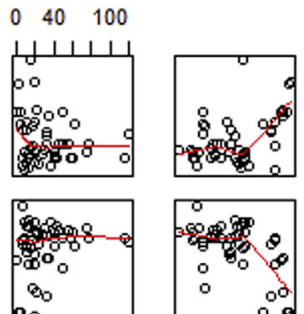

0
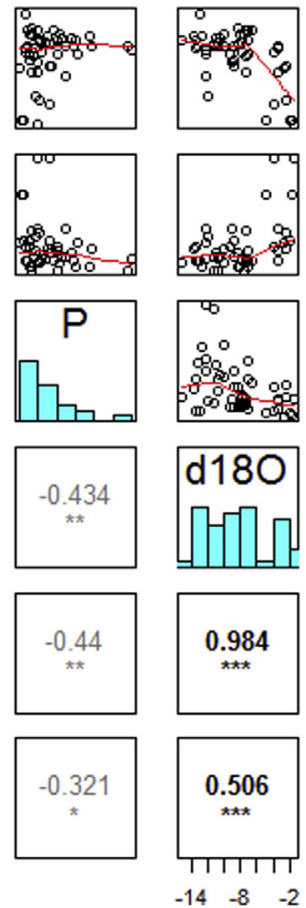
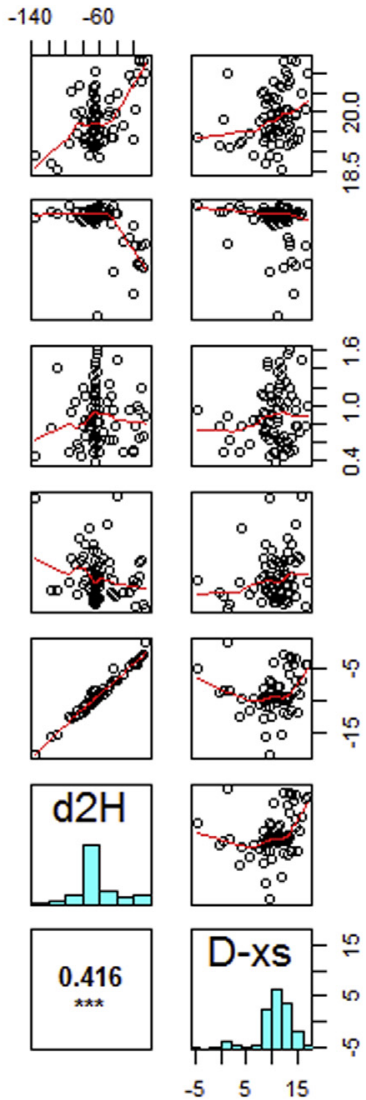

$\begin{array}{lll}-100 & -40\end{array}$
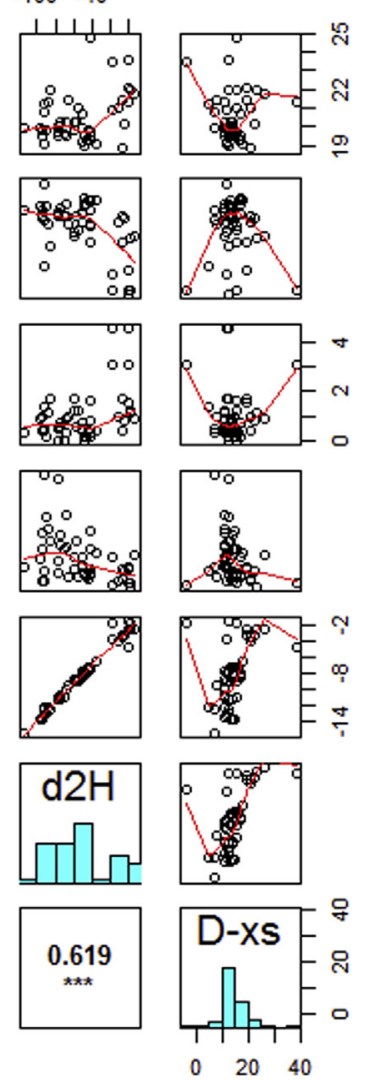
winds. Caño Seco is located within the South Pacific slope of the Talamanca Range at 1037 m.a.s.l. Caño Seco local climate is characterized by persistent rainfall events throughout the year with a mean annual precipitation of $3938 \mathrm{~mm}$ measured at sea level (Golfito, $20 \mathrm{~km}$ southwest of Caño Seco). However, it is likely that the annual precipitation at Caño Seco is lower compared to Golfito.

Daily samples in Heredia $(n=49)$ and Turrialba $(n=46)$ were collected using a passive collector, which consisted of a plastic funnel (diameter $=7.5-10 \mathrm{~cm}$ ) coupled with a filter mesh to prevent debris contamination. The funnel was connected to a $1 \mathrm{~L} \mathrm{high}$ density polyethylene (HDPE) container. A $2 \mathrm{~cm}$ layer of mineral oil (Rigoran Inc., Costa Rica) was added to prevent fractionation according with standard sampling protocols (IAEA, 2012). The mineral oil was separated using a $250-500 \mathrm{~mL}$ separatory funnel. Samples were stored upside down at $5{ }^{\circ} \mathrm{C}$ in HDPE bottles with conic and polyseal inserts and parafilm seals until analysis. Stable isotope analyses were conducted at the Chemistry School of the National University (Heredia, Costa Rica) using a Cavity Ring Down Spectroscopy (CRDS) water isotope analyzer L2120-i (Picarro, USA). Ratios of $\delta^{18} \mathrm{O} / \delta^{16} \mathrm{O}$ and $\delta^{2} \mathrm{H} / \delta^{1} \mathrm{H}$ are expressed in delta units (\%o, parts per mil) relative to Vienna Standard Mean Ocean Water (VSMOW). The analytical analyzer precision was $0.1 \% 0 \delta^{18} \mathrm{O} / \delta^{16} \mathrm{O}$ and $0.5 \% 0 \delta^{2} \mathrm{H} / \delta^{1} \mathrm{H}$. Daily samples in Caño Seco $(n=73)$ were collected using a passive sampler in the form of a modified tipping bucket rain gauge including a filter mesh. Mineral oil was applied and immediately decanted after daily sampling. Samples were completely filled into standard $3 \mathrm{ml}$ analytical vials and stored $5{ }^{\circ} \mathrm{C}$. Analyses were conducted in the isotope laboratory of the Northern Rivers Institute at the University of Aberdeen, Scotland using a Los Gatos DLT-100 Liquid Water Isotope Analyzer with a precision of $0.1 \% \circ \delta^{18} \mathrm{O} / \delta^{16} \mathrm{O}$ and $0.4 \% \delta^{2} \mathrm{H} / \delta^{1} \mathrm{H}$. In addition to stable isotope analysis of collected precipitation, 15 min surface meteorological data (i.e. precipitation amount, air temperature, wind speed, and relative humidity) were recorded during 2013.

\subsection{Sounding profiles}

Atmospheric sounding data from 2013 were obtained from the University of Wyoming, Department of Atmospheric Science database (http://weather.uwyo.edu/upperair/sounding.html) for two stations: the Juan Santamaría International Airport 78762 MROC (San José, Costa Rica) and Corozal 78807 MPCZ (Panamá Canal), with both data sets at 12 Z (UTC). Juan Santamaría International Airport station is about $9.6 \mathrm{~km}$ west of Heredia and thus is expected to closely represent Heredia's vertical atmospheric conditions. Since Caño Seco is located near the Panamá border and its climate regime shares strong similarities with those observed within the Pacific coast of Panamá, the Corozal sounding data were selected as a proxy for Caño Seco convective profiles. No available sounding data were collected near Turrialba that could represent the convective profiles at this station. Further statistical analyses were only conducted for Heredia and Caño Seco isotopic data sets. The availability of coeval daily sounding data and precipitation isotope values was $84 \%$ and $61 \%$ for Caño Seco and Heredia, respectively. The variables extracted for analyses from the corresponding sounding data were: CAPE (J/Kg), CAPEv (J/Kg), CIN (J/kg), $\operatorname{LFC}(\mathrm{m}), \operatorname{LFCv}(\mathrm{m}), \operatorname{LCLt}\left({ }^{\circ} \mathrm{C}\right), \operatorname{LCLp}(\mathrm{hPa}), \operatorname{MLR}$, and PW $(\mathrm{mm})$.

\subsection{HYSPLIT air mass back trajectories}

The influence of atmospheric trajectory on daily precipitation isotope composition was studied using the Hybrid Single-Particle Lagrangian Trajectory (HYSPLIT) model (Draxler and Rolph, 2015) (http://ready.arl.noaa.gov/HYSPLIT.php) developed by the National Oceanic and Atmospheric Administration (NOAA). HYSPLIT provides meteorological variables on hourly basis over the trajectory requested using a three-dimensional Lagrangian air mass velocity algorithm. Air parcel trajectories were modeled $48 \mathrm{~h}$ backwards in time due to the proximity of the Caribbean Sea and the Pacific Ocean. To compute a trajectory, the HYSPLIT model requires a starting time, location, and altitude as well as NOAA meteorological data files (e.g. GDAS1, global data assimilation system, $1^{\circ} \times 1^{\circ}, 2006$-present, Su et al., 2015). Based on meteorological conditions ( $\mathrm{T}$ and $\mathrm{RH}$ ) at each sampling, the altitude was entered as the LCL (m) using Lawrence's (2005) approximation. For the purpose of this analysis, a daily trajectory for each rain sample in Heredia $(n=49)$, Turrialba $(n=46)$, and Caño Seco $(n=73)$ was computed. Trajectories were further divided into dry (December-April) and wet (May-November) seasons.

\subsection{Statistical analysis}

Spearman's rank correlation analysis was performed to assess potential relationships between daily precipitation data and surface meteorological and sounding data at the three sites. The correlation results were reported as correlation matrices or bivariate plots. The latter additionally were used to visualize frequency distribution histograms of the data; the resulting correlation coefficients $r_{s}$ scaled to increasing size for different significance levels and scaled kernel regression smoothing indicate potential linear and non-linear relationships. Simple linear regression analysis was performed to construct a LMWL for each site. We also applied the machine learning technique Random Forests (randomForests $\mathrm{R}$ package) to analyze the isotopic data in relation to meteorological variables (see detailed description of the method in Breiman, 2001). This method can be used for classification, prediction and relative importance assessment of predictors. Random Forests was developed to improve predictions of regression trees by avoiding overfitting and was also reported to be more robust than simple linear regression, specifically for large datasets (e.g. Lawler et al., 2006). We attempted to construct parsimonious multiple linear regression (MLR) models using Random Forests to self-select predictors with a physical meaning. The relative importance of selected predictors in the regression models and their performance is reported using the mean squared error (MSE) and the \% increase of the MSE for model selection. Furthermore, the \% explained variance derived from the adjusted coefficient of determination $\left(\right.$ adj $R^{2}$ ) allows realistic comparison of different models as an increased number of parameters are penalized:

$a d j r^{2}=1-\left(\frac{n-1}{n-p-1}\right)\left(1-r^{2}\right)$

where $r^{2}$ is the coefficient of determination, $n$ is the number of observations, and $p$ is the number of predictors. The analysis was performed using the open source statistical $\mathrm{R}$ language and

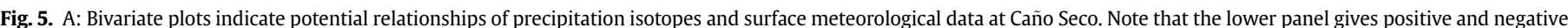

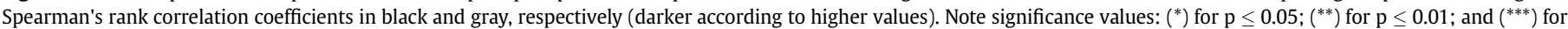

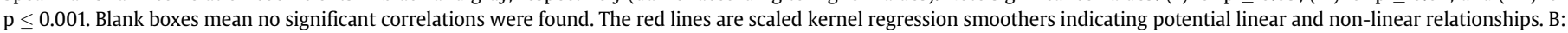

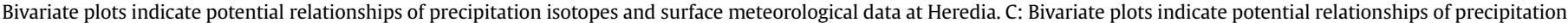

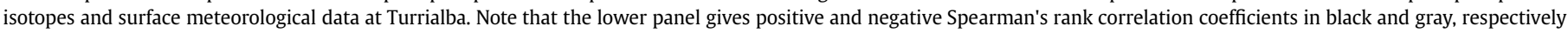
(darker according to higher values). (For interpretation of the references to colour in this figure legend, the reader is referred to the web version of this article.) 


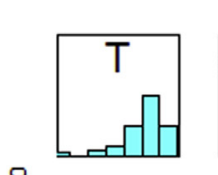

$\begin{array}{lll}80 & 90 & 100\end{array}$
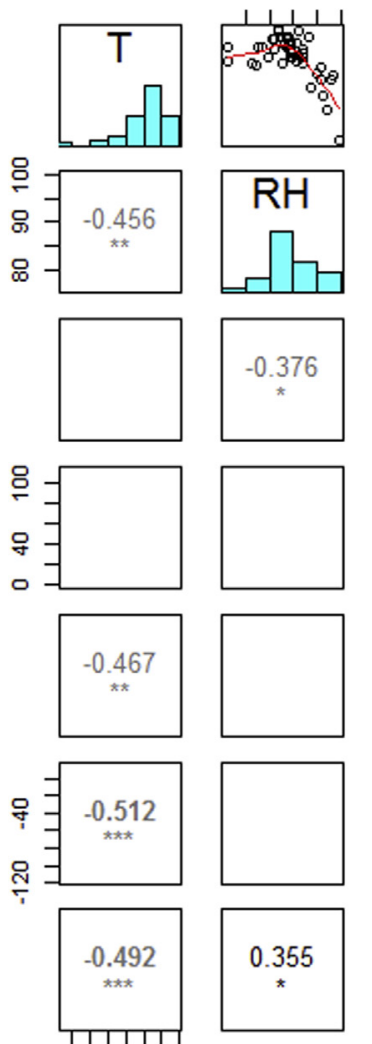

$\begin{array}{lll}15 & 18 & 21\end{array}$
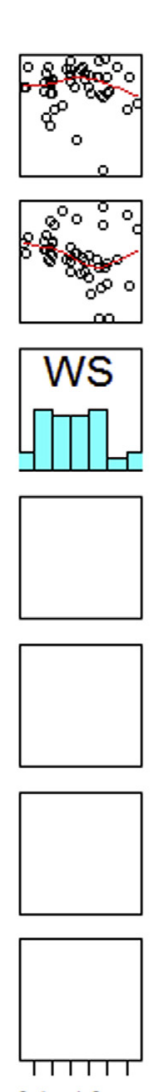
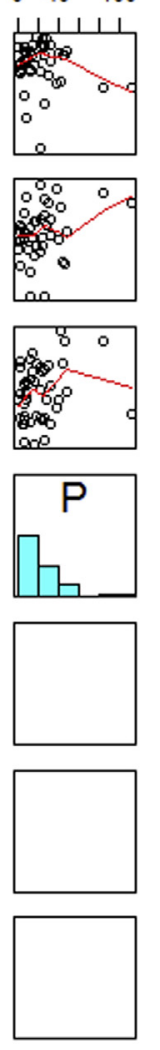

0.41 .0
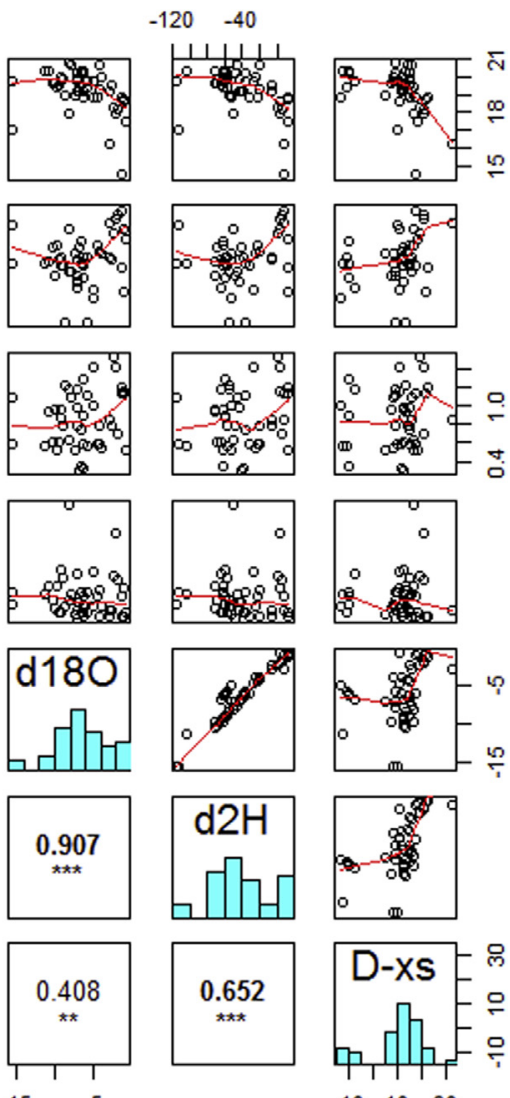

$-15 \quad-5$
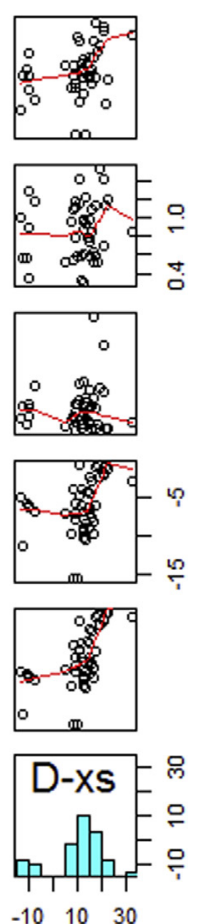

Fig. 5. (continued).

packages (R Development Core Team, 2014). In addition, a Kruskall-Wallis non-parametric test was conducted to determine significant differences in the $\delta^{2} \mathrm{H}$ and $\delta^{18} \mathrm{O}$ median ratios of the three study sites.

\section{Results and discussion}

\subsection{Precipitation anomalies in 2013}

Fig. 2A shows an overview of monthly precipitation regimes in the Central Valley (Heredia, 1982-2012), the Caribbean slope (Turrialba, 1942-2012), and the South Pacific slope (Golfito, $20 \mathrm{~km}$ southwest of Caño Seco, 1998-2012) based on available long-term records (National Meteorological Institute, 2014). The rainiest months in the Central Valley correspond to May-June and September-October; the same pattern occurs within the South Pacific. However, the influence of a persistent low pressure system located south of the Panama coast influences the precipitation regime in Golfito resulting in abundant precipitation events throughout the year, but primarily between May and November. The intensification of the easterlies during the boreal winter carries moisture from the Caribbean Sea producing a precipitation maxima in Turrialba in November and December. The orographic effect from the continental divide serves as a 'precipitation barrier' for the Central Valley resulting in a clear dry season from December to April. Fig. 2B-D shows the 2013 monthly precipitation standardized anomalies. In the South Pacific and the Caribbean slopes, precipitation amounts were substantially lower throughout 2013. Even though Caño Seco is not directly comparable to the Golfito long-term data due to a significant elevation difference, 2013 was the driest year of the three-year record from Caño Seco. In Heredia, negative standardized anomalies were observed predominantly at the beginning of the wet season and during the Mid-Summer Drought months (i.e. a precipitation deficit between August and July; Magaña et al., 1999) with above average rainfall from September to December.

\section{2. $\delta^{2} \mathrm{H}$ and $\delta^{18} \mathrm{O}$ in precipitation}

A Kruskall-Wallis non-parametric test revealed a significant difference $(p<0.001)$ in the $\delta^{2} \mathrm{H}$ and $\delta^{18} \mathrm{O}$ median ratios of the three study sites; therefore, all LMWLs were analyzed separately. The linear relationships of $\delta^{2} \mathrm{H}$ and $\delta^{18} \mathrm{O}$ ratios of precipitation samples collected in Heredia $(n=49)$, Turrialba $(n=46)$, and Caño Seco $(n=73)$ during 2013 are presented in Fig. 3 and compared to the GMWL. The $\delta^{2} \mathrm{H}$ and $\delta^{18} \mathrm{O}$ ratios of precipitation in Heredia ranged from $-114.7 \%$ to $+7.3 \%$ o and $-15.3 \%$ to $-1.5 \%$, respectively. A least squares regression of the precipitation isotope data resulted in a highly significant LMWL for Heredia: $\delta^{2} \mathrm{H}=8.65 \cdot \delta^{18} \mathrm{O}+19.8\left(r^{2}=0.97\right.$, Fig. 3$)$, with a mean annual $\delta^{18} \mathrm{O}$ of $-8.3 \%$. The $\delta^{2} \mathrm{H}$ and $\delta^{18} \mathrm{O}$ ratios in Turrialba varied from $-115.9 \%$ to $+13.7 \%$ and $-15.5 \%$ to $-0.85 \%$, respectively. A least squares regression of the precipitation isotope data resulted in a significant Turrialba meteoric water line: $\delta^{2} \mathrm{H}=8.72 \cdot \delta^{18} \mathrm{O}+17.9\left(r^{2}=0.98\right.$, Fig. 3$)$, with mean $\delta^{18} \mathrm{O}$ of $-6.3 \%$. In Caño Seco, $\delta^{2} \mathrm{H}$ and $\delta^{18} \mathrm{O}$ ratios ranged from $-135.9 \%$ o to $-5.6 \%$ and $-18.7 \%$ o to $-0.89 \%$, respectively. A least squares regression of the precipitation isotope data resulted in a significant LMWL for Caño Seco: $\delta^{2} \mathrm{H}=8.21 \cdot \delta^{18} \mathrm{O}+12.2\left(r^{2}=0.98\right.$, Fig. 3$)$, with a mean annual $\delta^{18} \mathrm{O}$ of $-8.9 \%$. 
Isotope ratios in sporadic dry season (Dec-April) rainfall events are mostly related to small enriched events (Fig. 4A, Table 2). By mid-May, when the ITCZ travels over Costa Rica, a sharp depletion in isotope ratios was observed (Table 2). Shifting of the ITCZ to the north and the prevalence of Mid-Summer Drought conditions across Central America increases the isotopic variability throughout the wet season. The high slopes of the LMWL (8.2-8.7) observed at the three sites are an artifact introduced by the dry season sample values which exhibited high $d$-excess values. Others have explained high intercepts and slopes to enhanced moisture recycling processes, such as localized strong convective events fed by evapotranspiration fluxes, whereby $d$-excess increases as a result of increased evaporate content (Gat and Matsui, 1991; Froehlich et al., 2002). Mean annual d-excess values ranged from $+10.3 \%$ (Caño Seco) and $+10.6 \%$ (Turrialba) up to $+14.4 \%$ (Heredia). Although temperature seasonality was similar among the three sites (Fig. 4B), Caño Seco and Turrialba exhibited a greater relative humidity than Heredia (close to saturation during the wet season) (Fig. 4C). The precipitation anomalies mentioned above resulted in similar annual cumulative precipitation volumes (Fig. 4D). Surface meteorological conditions were used to further evaluate the isotopic variations.

\section{3. $\delta^{18} \mathrm{O}, \delta^{2} \mathrm{H}$, and surface meteorological and sounding data}

An exploratory Spearman's correlation analysis was conducted between surface meteorological variables and daily isotope composition to determine whether the empirical 'amount effect' or other relationships may be present on a dailyscale (Fig. 5A, B, and C). Overall, precipitation amounts and $\delta^{18} \mathrm{O}$ exhibited a non-significant negative correlation among the three sites, suggesting that other physical processes may control the isotopic variations. In Heredia and Turrialba, there is a significant positive correlation between wind speed and isotope ratios (based on surface meteorological observations) most likely related to the influence of strong trade winds and moisture transport from the Caribbean lowlands to the Central Valley through the Palma Depression. Since the analysis of convective system organization at meso and large scales have been proposed as a rationale to better understand isotopic variations (Kurita, 2013), surface meteorological and available sounding data were combined to further explore the influence of these convective processes. Significant Spearman's correlation coefficients between precipitation isotopes and LCL $\left(0.37<r_{s}<0.48\right)$ at both sites support the notion of the importance of sounding profiles to enhance understanding of precipitation isotopic variations (Table 3 ).

The best-performing and most parsimonious Random Forests
MLR models included as expected identical predictor variables for both isotopes, but different models were selected for the Heredia and Caño Seco site reflecting the spatial variability of influencing microclimatic systems. The precipitation isotopes collected at the South Pacific slope (Caño Seco) site were most significantly related to $\mathrm{RH}, \mathrm{LCL}$, and $\mathrm{T}$ (ordered according to relative importance, Fig. 6a). These self-selected predictor variables reflect the nearsurface (RH, T) and vertical (LCL) atmospheric processes related to potential isotopic exchange and can therefore, be considered physically meaningful. This three-parameter MLR model resulted in a MSE $=5.3$ and $67.9 \%$ overall explained variance for $\delta^{18} \mathrm{O}$ and in a MSE $=341$ and $61.4 \%$ overall explained variance for $\delta^{2} \mathrm{H}$. In comparison, for the isotopes at Heredia a four-parameter (from most to least important: LCL, PW, RH, and P) MLR model was selected. Additionally to RH and LCL this model uses the amount of PW over the vertical profile together with the near-surface precipitation volumes to explain the isotopic composition of rain waters. The Heredia model consists of one additional parameter compared to the Cano Seco model, but can still be considered physically meaningful as all included variables relate to isotopic exchange processes near the surface and over the vertical profile. The latter model resulted in a MSE $=15.1$ and $47.3 \%$ explained variance for $\delta^{18} \mathrm{O}$ and for $\delta^{2} \mathrm{H}$ in a MSE $=1146.4$ and $42.2 \%$ of explained variance (Fig. 6b). Generally, the model selected for Caño Seco outperformed the Heredia model and $\delta^{18} \mathrm{O}$ models seem to be more accurate compared to $\delta^{2} \mathrm{H}$. The model performance is further visualized using an $\mathrm{x}-\mathrm{y}$ plot of predicted against observed isotopes at both sites and the simulated deuterium isotope time series at Heredia (Fig. 7). The models clearly match the seasonal dynamics correctly simulating more enriched isotopic values during the dry and early rainy season and much more depleted values towards the end of the rainy season in November. Despite reproducing the general trends quite well, the models are not capable of matching the most extreme (enriched and depleted) isotope values.

\subsection{Parental moisture source: HYSPLIT air mass back trajectories}

The identification of the parental moisture source of daily precipitation events sampled in the three study sites was computed using an analysis of air mass back trajectories. Fig. 8A and B shows the HYSPLIT trajectories for the dry and wet season in 2013, respectively. The wind direction and velocity in the study region is greatly influenced by the seasonal migration of the ITCZ. During the dry season, when the ITCZ is located south of Costa Rica, air masses travel in a northeasterly direction across the country (Fig. 8A); as the air masses enter the continental Caribbean lowlands the moisture transport is affected mainly by the Central Volcanic Range

Table 3

Spearman's rank correlation matrix using sounding profile data in combination with precipitation isotopes at Heredia (gray panel) and Caño Seco (clear panel) .

\begin{tabular}{|c|c|c|c|c|c|c|c|c|c|c|c|c|c|}
\hline Variables & $\delta^{18} \mathrm{O}$ & $\delta{ }^{2} \mathrm{H}$ & D-Xs & CAPE & CAPEv & CIN & LFC & LFCV & LCLt & LCLp & LCL & MR & PW \\
\hline$\delta^{18} \mathrm{O}$ & & 0.98 & 0.36 & -0.13 & -0.06 & 0.00 & -0.16 & -0.11 & -0.07 & -0.11 & 0.48 & -0.02 & -0.20 \\
\hline$\delta^{2} \mathrm{H}$ & 0.94 & & 0.51 & -0.14 & -0.06 & 0.04 & -0.14 & -0.09 & -0.06 & -0.10 & 0.46 & -0.01 & -0.23 \\
\hline D-Xs & 0.21 & 0.41 & & -0.10 & -0.05 & 0.12 & -0.05 & -0.04 & -0.02 & -0.04 & 0.03 & 0.00 & -0.01 \\
\hline CAPE & -0.30 & -0.30 & -0.14 & & 0.98 & -0.23 & 0.66 & 0.66 & 0.72 & 0.38 & -0.19 & 0.78 & 0.64 \\
\hline CAPEV & -0.30 & -0.29 & -0.12 & 1.00 & & -0.19 & 0.63 & 0.66 & 0.80 & 0.45 & -0.15 & 0.86 & 0.63 \\
\hline CIN & -0.16 & -0.26 & -0.21 & 0.32 & 0.31 & & -0.02 & 0.00 & -0.04 & 0.03 & 0.15 & -0.04 & -0.27 \\
\hline LFC & -0.27 & -0.40 & -0.35 & 0.27 & 0.26 & 0.78 & & 0.96 & 0.50 & 0.24 & -0.20 & 0.56 & 0.43 \\
\hline LFCV & -0.29 & -0.40 & -0.36 & 0.35 & 0.34 & 0.82 & 0.90 & & 0.60 & 0.37 & -0.27 & '0.64 & 0.41 \\
\hline LCLt & -0.31 & -0.30 & -0.15 & 0.89 & 0.89 & 0.48 & 0.45 & 0.51 & & 0.85 & -0.34 & 0.98 & 0.51 \\
\hline LCLp & -0.20 & -0.25 & -0.21 & 0.55 & 0.54 & 0.61 & 0.60 & 0.62 & 0.78 & & -0.51 & 0.76 & 0.38 \\
\hline $\mathrm{LCL}$ & 0.37 & 0.46 & 0.40 & -0.15 & -0.14 & -0.29 & -0.41 & -0.36 & -0.27 & -0.37 & & -0.25 & -0.51 \\
\hline MR & -0.32 & -0.31 & -0.11 & 0.93 & 0.92 & 0.42 & 0.39 & 0.44 & 0.98 & 0.69 & -0.26 & & 0.50 \\
\hline PW & -0.27 & -0.32 & -0.30 & 0.46 & 0.42 & 0.41 & 0.51 & 0.48 & 0.63 & 0.67 & -0.52 & 0.60 & \\
\hline
\end{tabular}



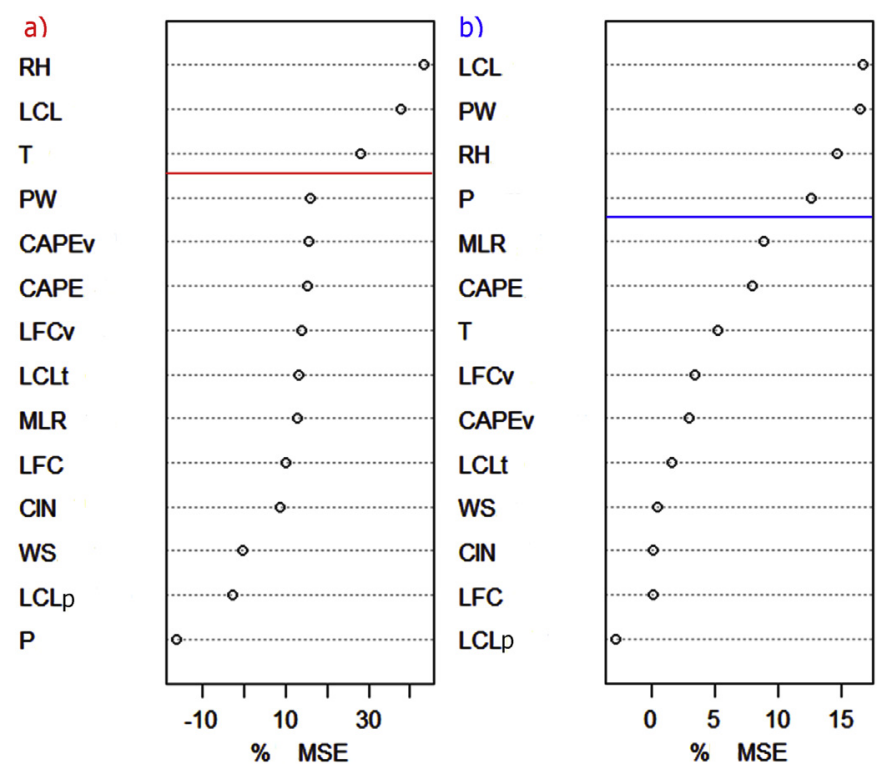

Fig. 6. Automatic predictor selection among surface meteorological and sounding profile data using the machine learning technique Random Forests. The color coding corresponds to a) the Caño Seco and b) the Heredia site. The lines indicate the breakpoint of variables included in a MLR model to predict $\delta^{2} \mathrm{H}$ as an example based on their relative importance as determined by the \% increase of the explained variance of each individual predictor. (For interpretation of the references to colour in this figure legend, the reader is referred to the web version of this article.)

(Lachniet et al., 2007; Duran-Quesada et al., 2010); consequently, water molecules experience orographic distillation when crossing the Palma Depression. The Palma Depression is a pass between two main volcano massifs with altitudes ranging from 2906 m.a.s.l. (Barva Volcano) up to 3432 m.a.s.l. (Irazú Volcano). Moisture derived from the Caribbean Sea basin travels across this pass where significant distillation $\left(\sim 2 \% \delta^{18} \mathrm{O} / \mathrm{km}\right.$ of air mass lifting $)$ has been reported by Sánchez-Murillo et al. (2013) (Fig. 1B). Wind direction during the dry season is controlled by a regional moisture transport mechanism, the Caribbean Low Level Jet (CLLJ) (Duran-Quesada et al., 2010). This water vapor transport pattern is associated with enriched rainfall events whereby recycled evapotranspiration fluxes mix with the air masses travelling along the Caribbean

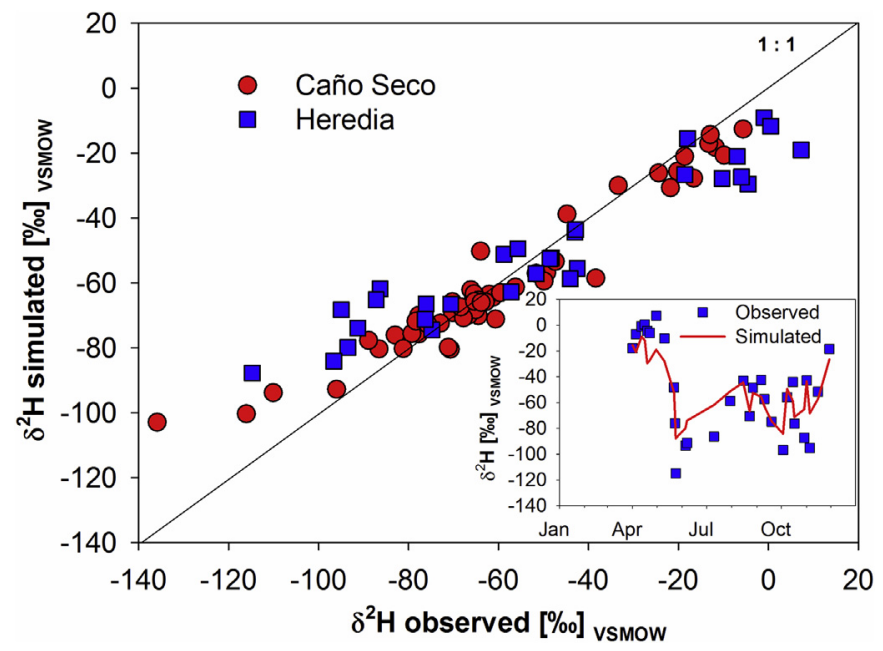

Fig. 7. The $x-y$ plot of observed against simulated $\delta^{2} \mathrm{H}$ signatures at Heredia and Caño Seco shows the goodness-of-fit of the MLR models. The inset graph demonstrates the simulated $\delta^{2} \mathrm{H}$ time series (red line) in relation to observed values at Heredia. (For interpretation of the references to colour in this figure legend, the reader is referred to the web version of this article.) lowlands (Fig. 8A). During the wet season, the precipitation regime is controlled by the presence of the ITCZ across Central America. When the ITCZ moves northward, cross-equatorial winds from the southern hemisphere recurve to become southwesterly and transport Pacific parental moisture to Costa Rica combined with a weakening of trade winds (Lachniet et al., 2007). As a result, intensification in the genesis and development of deep convection systems on the Pacific coast of Costa Rica occurs; generally this phenomenon is associated with the presence of the "Chorro del Occidente Colombiano' or CHOCO jet (Fig. 8B) (Duran-Quesada et al., 2010). Because of its location on the Pacific Slope, Caño Seco received abundant precipitation events under the influence of this convection system, whereas Heredia and Turrialba are topographically isolated from this influence during most of the wet season (Fig. 8B). In addition, precipitation events arriving to the Central Valley from the Pacific Ocean undergo a noticeable orographic distillation when the air masses are lifted over the Continental Divide barrier (Sánchez-Murillo et al., 2013), resulting in depleted isotopic samples in Heredia (mean $=-8.3 \% \delta^{18} \mathrm{O}$ ). In contrast, air masses traveling across the Caribbean lowlands are generally $\sim 2 \%$ more enriched as in the case of Turrialba (mean $=-6.3 \% 0 \delta^{18} \mathrm{O}$ ). In Caño Seco, the influence of the Talamanca range (See Fig. 1) (highest altitude 3820 m.a.s.l.) induces strong orographic distillation resulting in a mean annual $\delta^{18} \mathrm{O}$ ratio of $-8.8 \%$ (Table 2 ).

\subsection{Assessing key drivers of isotopic composition in precipitation}

Since the pioneering work by Dansgaard (1964), the key drivers affecting $\delta^{18} \mathrm{O}$ and $\delta^{2} \mathrm{H}$ ratios in maritime and continental meteoric waters have been debated. Regularly, the monthly cumulative precipitation volume has been strongly correlated with isotopic variations. The rationale behind the empirical 'amount effect' relies on the idea that isotopic equilibration with the enriched vapor below the cloud base is more complete with the small raindrops associated with light rains. Water vapor near the surface has higher $\delta^{18} \mathrm{O}$ because of the effect of $\delta^{18} \mathrm{O}$ enriched vapor from surface evaporation. Therefore, lighter rainfall events (i.e. lower volume) will favor isotopic exchange with surrounding moisture and are subject to a more effective secondary evaporation below the cloud base. During heavy rainfall events (i.e. large volume), relative humidity below the cloud base is greater (indicated by bivariate plots, Fig. $5 \mathrm{~A}-\mathrm{C}$ ) and thus the moisture exchange is lower as well as the probability of secondary evaporation as water falls to the surface. This explanation has been successful when analyzing monthly composite samples that may represent more regional precipitation patterns. Nevertheless, in tropical regions such as Central America, our findings suggest that convective systems are often attributed to localized moisture recycling; therefore, the 'amount effect' relationship is no longer useful to explain the observed isotopic variations. The insignificant 'amount effect' is further emphasized analyzing seasonal $d$-excess variations among the three sites (Fig. 9). High $d$-excess (mean $=+17.8 \%$, ranging from $+9.8 \%$ up to $+26.6 \%$ ) among all the three sites were observed during the dry season months (December-April) when evaporation occurs under conditions of lower relative humidity (Fig. 4c) and a higher LCL (Heredia, mean LCL $487 \mathrm{~m}$ ). During the dry season, on daily timescales independent of precipitation amount the longer the molecule travel time from the cloud base to the surface the greater the isotopic enrichment. During the rainy season, local convective systems have lower LCL heights (Caño Seco, mean LCL $278 \mathrm{~m}$ ), therefore, a shorter molecule travel distance under humidity conditions close to saturation reduces the change of secondary evaporation resulting in depleted ratios. 

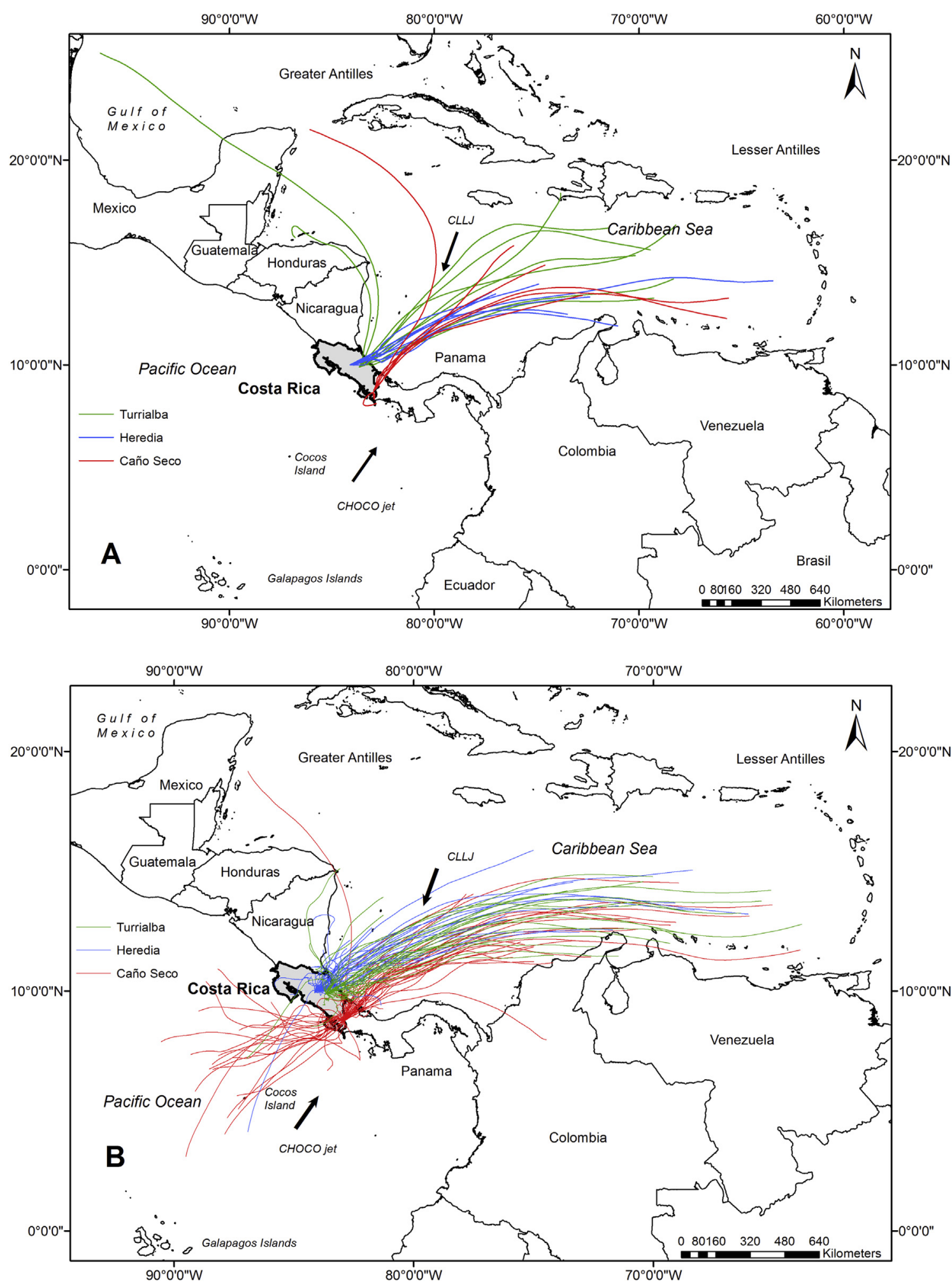

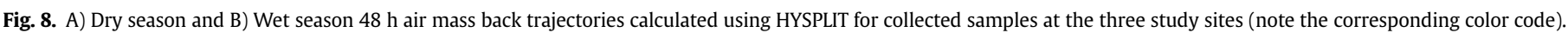
(For interpretation of the references to colour in this figure legend, the reader is referred to the web version of this article.)

\section{Conclusions}

In this study we report on the isotope composition of daily precipitation at three sites across Costa Rica for the year 2013. This was done with the aim of assessing the key drivers controlling isotope variability within this region of Central America. Contrary to the previously reported monthly 'amount effect', precipitation volume plays a rather minor role explaining daily-scale isotope variability in tropical meteoric waters. The most important drivers (as assessed by Spearman's rank correlation and Random Forests 


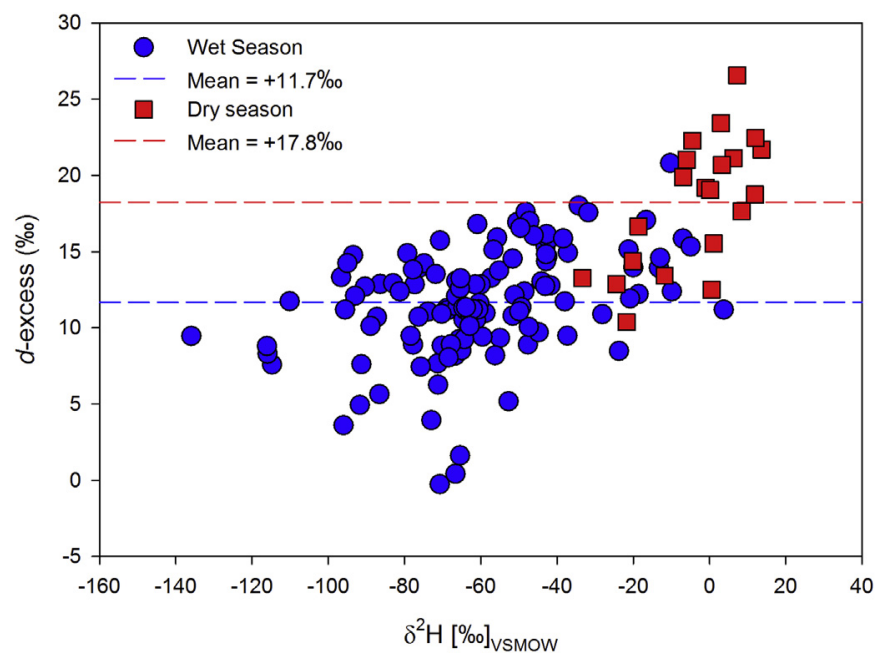

Fig. 9. Seasonal variation of $d$-excess (\%o) (three sites combined) and $?^{2} \mathrm{H}(\% 0)$ during 2013. Blue dots and red squares represent the wet and dry seasons, respectively. The mean d-excess in the wet season is $+11.7 \%$, which increases in the dry season to a mean of $+17.8 \%$. (For interpretation of the references to colour in this figure legend, the reader is referred to the web version of this article.)

MLR analyses) were the lifted condensation level and relative humidity. Both variables explained over $70 \%$ of the variance in MLR models that predict daily precipitation isotope time series. The selfselected MLR models resulted in parsimonious ( $\leq 4$ parameters) and physically-sound explanations of the isotopic composition of precipitation patterns. Together with HYSPLIT air mass back trajectories we were able to further relate the diverse origin of moisture and transport mechanisms to the observed daily isotopic variability. The results of this study help to better understand the factors influencing daily-scale precipitation isotopes here and elsewhere within Central America with strong implications for water resource management. Furthermore, the results of this study could help identify the likely origin of rainfall recharging groundwater and the aquifer's susceptibility to drought induced by a prolonged Pacific dry season as well as improving the reconstruction of paleoclimatic records in the Central America land bridge.

\section{Acknowledgments}

This project was supported by International Atomic Energy Agency grant CRP-19747 to RSM under the initiative "Stable isotopes in precipitation and paleoclimatic archives in tropical areas to improve regional hydrological and climatic impact models." Sampling conducted in Turrialba (Coffee-Flux Observatory, http:// www6.montpellier.inra.fr/ecosols/Recherche/Les-projets/ CoffeeFlux) was supported by a National Science Foundation-IGERT Fellowship (Grant no. 0903479), US Borlaug Fellowship in Global Food Security to KW and by SOERE-F-ORE-T network of observatories, Ecosfix project (ANR-10-STRA-003-001), Macacc project (ANR-13-AGRO-0005) and CIRAD-IRD SAFSE-Project. CB and RAM would like to thank various helping hands in the field (Carlos Mendez Blanco, Gonzalo Salazar Salazar) and support from the University of Costa Rica (project VI-B2235 and 217-B4-239) and the University of Aberdeen (Doerthe Tetzlaff and Josie Geris).

\section{References}

Aggarwal, P.K., Alduchov, O.A., Froehlich, K.O., Araguas-Araguas, L.J., Sturchio, N.C., Kurita, N., 2012. Stable isotopes in global precipitation: a unified interpretation based on atmospheric moisture residence time. Geophys. Res. Lett. 39, L11705.
http://dx.doi.org/10.1029/2012GL051937.

Araguás-Araguás, L., Froehlich, K., Rozanski, K., 1998. Stable isotope composition of precipitation over southeast Asia. J. Geophys. Res. 103 (22), 28,721-28,742.

Araguás-Araguás, L., Froehlich, K., Rozanski, K., 2000. Deuterium and oxygen-18 isotope composition of precipitation and atmospheric moisture. Hydrol. Process. 14, 230-244.

Barras, V., Simmonds, I., 2009. Observation and modeling of stable water isotopes as diagnostics of rainfall dynamics over southeastern Australia. J. Geophys. Res. 114 (D23), D23308.

Berden, G., Peeters, R., Meijer, G., 2000. Cavity ring-down spectroscopy: experimental schemes and applications. Int. Rev. Phys. Chem. 19 (4), 565-607.

Berman, E.S.F., Levin, N.E., Landais, A., Li, S., Owano, T., 2013. Measurement of $\delta 180$, $\delta 170$, and 170 - excess in water by Off-Axis integrated cavity output spectroscopy and isotope ratio mass spectrometry. Anal. Chem. 85, 10392-10398. 10. 1021 /ac402366t.

Birkel, C., Soulsby, C., Tezlaff, D., Dunn, S., Spezia, L., 2012. High-frequency storm event isotope sampling reveals time-variant transit time distributions and influence of diurnal cycles. Hydrol. Process 26, 308-316. http://dx.doi.org/ 10.1002/hyp.8210.

Bowen, G., 2008. Spatial analysis of the intra-annual variation of precipitation isotope ratios and its climatological corollaries. J. Geophys. Res. 113 (D5), D05113.

Bowen, G.J., Revenaugh, J., 2003. Interpolating the isotopic composition of modern precipitation. Water Resour. Res. 39 (10), 1299. http://dx.doi.org/10.1029/ 2003 WR002086.

Breiman, L., 2001. Random forests. Mach. Learn. 45, 5-32.

Celle-Jeanton, H., Gonfiantini, R., Travi, Y., Sol, B., 2004. Oxygen-18 variations of rainwater during precipitation: application of the Rayleigh model to selected rainfalls in Southern France. J. Hydrol. 298, 165-177.

Cobb, K.M., Adkins, J.F., Partin, J.W., Clark, B., 2007. Regional-scale climate influences on temporal variation of rainwater and cave dripwater oxygen isotopes in northern Borneo. Earth Planet. Sci. Lett. 263, 207-220.

Coplen, T., Neiman, P., White, A., Landwehr, J.M., Ralph, F.M., Dettinger, M.D., 2008 Extreme changes in stable hydrogen isotopes and precipitation characteristics in a landfalling Pacific storm. Geophys. Res. Lett. 35, L21808. http://dx.doi.org/ 10.1029/2088GL035481.

Craig, H., 1961. Isotopic variations in meteoric waters. Science 133, 1702-1703.

Dansgaard, W., 1964. Stable isotopes in precipitation. Tellus 16 (4), 436-468.

Duran-Quesada, A.M., Gimeno, L., Amador, J.A., Nieto, R., 2010. Moisture sources for Central America: identification of moisture sources using a Lagrangian analysis technique. J. Geophys. Res. 115, D05103. http://dx.doi.org/10.1029/ 2009JD012455.

Froehlich, K., Gibson, J.J., Aggarwal, P., 2002. Deuterium excess in precipitation and its climatological significance. in study of environmental change using isotope techniques. Proc. Intern. Conf. 54-66.

Gat, J., Matsui, E., 1991. Atmospheric water balance in the Amazon Basin: an isotopic evaporation model. J. Geophys. Res. Atmos. 96, (D7), 13,179-13,188.

Gómez-Delgado, F., Roupsard, O., Le Maire, G., Taugourdeau, S., Pérez, A., van Oijen, M., Vaast, P., Rapidel, B., Harmand, J.M., Voltz, M., Bonnefond, J.M., Imbach, P., Moussa, R., 2011. Modelling the hydrological behaviour of a coffee agroforestry basin in Costa Rica. Hydrol. Earth Syst. Sci. 15, 369-392.

Good, S.P., Mallia, D.V., Lin, J.C., Bowen, G.J., 2014. Stable isotope analysis of precipitation samples obtained via Crowdsourcing reveals the spatiotemporal evolution of superstorm sandy. PLoS ONE 9 (3), e91117. http://dx.doi.org/ 10.1371/journal.pone.0091117.

Gupta, P., Noone, D., Galewsky, J., Sweeney, C., Vaughn, B.H., 2009. Demonstration of high-precision continuous measurements of water vapor isotopologues in laboratory and remote field deployments using wavelength-scanned cavity ring-down spectroscopy (WS-CRDS) technology. Rapid Commun. Mass Spectrom. 23 (16), 2534-2542. http://dx.doi.org/10.1002/rcm.4100.

Guswa, A.J., Rhodes, A., Newell, S.E., 2007. Importance of orographic precipitation to the water resources of Monteverde, Costa Rica. Adv. Water Resour. 30, 2098-2112.

International Atomic Energy Agency (IAEA), 2012. Technical Procedures for GNIP Stations. Vienna, Austria, p. 12. Available at. http://www-naweb.iaea.org/napc/ ih/IHS_resources_gnip.html.

Ichiyanagi, K., Yamanaka, M.D., 2005. Interannual variation of stable isotopes in precipitation at Bangkok in response to El Niño southern oscillation. Hydrol. Process. 19, 3413-3423.

Ishizaki, Y., Yoshimura, K., Kanae, S., Kimoto, M., Kurita, N., Oki, T., 2012. Interannual variability of $\mathrm{H}_{2}^{18} \mathrm{O}$ in precipitation over the Asian monsoon region. J. Geophys. Res. 117, D16308. http://dx.doi.org/10.1029/2011JD015890.

Johnson, K.R., Ingram, B.L., 2004. Spatial and temporal variability in the stable isotope systematics of modern precipitation in China; implications for paleoclimate reconstructions. Earth Planet. Sci. Lett. 220, 365-377. http://dx.doi.org/ 10.1016/S0012-821X(04)00036-6.

Kurita, N., 2013. Water isotopic variability in response to mesoscale convective system over the tropical ocean. J. Geophys. Res. Atmos. 118 (18), $10,376-10,390$.

Kurita, N., Ichiyanagi, K., Matsumoto, J., Yamanaka, M.D., Ohata, T., 2009. The relationship between the isotopic content of precipitation and the precipitation amount in tropical regions. J. Geochem. Explor. 102 (3), 113-122.

Lachniet, M., 2009a. Climatic and environmental controls on speleothem oxygenisotope values. Quat. Sci. Rev. 28 (5-6), 412-432. http://dx.doi.org/10.1016/ j.quascirev.2008.10.021. 
Lachniet, M., 2009b. Sea surface temperature control on the stable isotopic composition of rainfall in Panama. Geophys. Res. Lett. 36, L03701. http:// dx.doi.org/10.1029/2008GL036625.

Lachniet, M., Paterson, W.P., 2002. Stable isotope values of Costa Rican surface waters. J. Hydrology 260, 135-150.

Lachniet, M., Paterson, W., 2009. Oxygen isotope values of precipitation and surface waters in northern Central America (Belize and Guatemala) are dominated by temperature and amount effects. Earth Planet. Sci. Lett. 284, 435-446.

Lachniet, M., Paterson, W.P., Burns, S., Asmerom, Y., Polyak, V., 2007. Caribbean and Pacific moisture sources on the Isthmus of Panama revealed from stalagmite and surface water d180 gradients. Geophys. Res. Lett. 34, L01708. http:// dx.doi.org/10.1029/2006GL028469.

Lawler, J.J., White, D., Neilson, R.P., Blaustein, A.R., 2006. Predicting climate-induced range shifts: model differences and model reliability. Glob. Clim. Change Biol. $12,1568-1584$

Lawrence, M., 2005. The relationship between relative humidity and the dewpoint temperature in moist air: a simple conversion and applications. Bull. Am. Meteorol. Soc. 225-233.

Lawrence, J.R., Gedzelman, S.D., Dexheimer, D., Cho, H.K., Carrie, G.D., Gasparini, R. Anderson, C.R., Bowman, K.P., Biggerstaff, M.I., 2004. Stable isotopic composition of water vapor in the tropics. J. Geophys. Res. Atmos. 109 (D6) (1984-2012).

Magaña, V., Amador, J.A., Medina, S., 1999. The midsummer drought over Mexico and Central America. J. Clim. 12 (1967), 1577-1588.

McGlynn, B., McDonnel, J.J., Brammer, D.D., 2002. A review of the evolving perceptual model of hillslope flowpaths at the Maimai catchments, New Zealand. Hydrology 257, 1-26.

Melchiorre, E.B., Talyn, B.C., Pregger, K., 2009. Oxygen and hydrogen stable isotope maps for meteoric groundwater in Costa Rica, excluding geothermal waters. Environ. Hydrol. 17, 1-16.

Moerman, J.W., Cobb, K.M., Adkins, J.F., Sodemann, H., Clark, B., Tuen, A., 2013. Diurnal to interannual rainfall $\delta^{18} \mathrm{O}$ variations in northern Borneo driven by regional hydrology. Earth Planet. Sci. Lett. 369-370, 108-119. http://dx.doi.org/ 10.1016/j.epsl.2013.03.014.

Munksgaard, N.C., Wurster, C.M., Bass, A., Bird, M.I., 2012. Extreme short-term stable isotope variability revealed by continuous rainwater analysis. Hydrol. Process. 26, 3630-3634. http://dx.doi.org/10.1002/hyp.9505.

Munksgaard, N.C., Zwart, C., Kurita, N., Bass, A., Nott, J., Bird, M.I., 2015. Stable isotope anatomy of tropical cyclone Ita, North-Eastern Australia, april 2014 PLoS ONE 10 (3), e0119728. http://dx.doi.org/10.1371/journal.pone.0119728.

Muñoz, A.C., Fernández, W., Gutiérrez, J.A., Zarate, E., 2002. Variación estacional del viento en Costa Rica y su relación con los regímenes de lluvia. Tópicos Meteorol Ocean. 9 (1), 1-13.

National Meteorological Institute, 2014. Long-term Rainfall Averages for Heredia Turrialba, and Caño Seco (Sán José, Costa Rica).

Okazaki, A., Satoh, Y., Tremoy, G., Vimeux, F., Scheepmaker, R., Yoshimura, K., 2015. Interannual variability of isotopic composition in water vapor over western Africa and its relationship to ENSO. Atmos. Chem. Phys. 15 (6), 3193-3204.

Panarello, H.O., Dapeña, C. 2009. Large scale meteorological phenomena, ENSO and ITCZ, define the Paraná River isotope composition. J. Hydrology 365, 105-112.

Reynolds-Vargas, J., Fraile, J., 2009. Utilización de isotópos estables en la precipitación para determinar zonas de recarga del acuífero Barva, Costa Rica. In: Estudios de Hidrología Isotópica en América Latina 2006. International Atomic Energy Agency, pp. 83-96. IAEA-TECDOC-1611.

Rhodes, A., Guswa, A.J., Newell, S.E., 2006a. Seasonal variation in the stable isotopic composition of precipitation in the tropical montane forests of Monteverde Costa Rica. Water Res. 42, W11402. http://dx.doi.org/10.1029/2005WR004535.

Rhodes, A.L., Guswa, A.J., Newell, S.E., 2006b. Seasonal variation in the stable isotopic composition of precipitation in the tropical montane forests of Monteverde, Costa Rica. Water Resour. Res. 42 (11), 1-17.

Risi, C., Bony, S., Vimeux, F., 2008. Influence of convective processes on the isotopic composition $\left(\delta^{18} \mathrm{O}\right.$ and $\left.\delta \mathrm{D}\right)$ of precipitation and water vapor in the tropics: 2 . Physical interpretation of the amount effect. J. Geophys. Res. 113, D19306. http://dx.doi.org/10.1029/2008JD00943.

Risi, C., Noone, D., Frankenberg, C., Worden, J., 2013. Role of continental recycling in intraseasonal variations of continental moisture as deduced from model simulations and water vapor isotopic measurements. Water Resour. Res. 49, 4136-4156.

Rolph, G.D., 2015. Real-time Environmental Applications and Display System (READY). NOAA Air Resources Laboratory, Silver Spring, MD website. http:/ ready.arl.noaa.gov.

Rozanski, K., Sonntag, C., Münnich, K.O., 1982. Factors controlling isotopic composition of European precipitation. Tellus 34, 142-150. http://dx.doi.org/10.1111/ j.2153-3490.1982.tb01801.x.

Rozanski, K., Araguas-Araguas, L.J., Gonantini, R., 1993. Isotopic patterns in modern global precipitation. In: Swart, P.K., Lohmann, K.C., McKenzie, J., Savin, S. (Eds.), Climate Change in Continental Isotopic Records. American Geophysical Union, Washington, pp. 1-36. Geophysical Monograph No 67.

Sánchez-Murillo, R., Esquivel-Hernández, G., Welsh, K., Brooks, E.S., Boll, J., AlfaroSolís, R., Valdés-González, J., 2013. Spatial and temporal variation of stable isotopes in precipitation across Costa Rica: an analysis of historic GNIP records. Mod. Hydrol. 3, 226-240. http://dx.doi.org/10.4236/ojmh.2013.34027.

Sánchez-Murillo, R., Brooks, E.S., Elliot, W., Boll, J., 2015. Isotope hydrology and baseflow geochemistry in natural and human-altered watersheds in the Inland Pacific Northwest, USA. Stable Isot. Environ. Health Stud. 51 (2), 231-254. http://dx.doi.org/10.1080/10256016.2015.1008468.

Scholl, M.A., Shanley, J.B., Zegarra, J.P., Coplen, T.B., 2009. The stable isotope amount effect: new insights from NEXRAD echo tops, Luquillo Mountains, Puerto Rico. Water Resour. Res. 45 (12), WR12407.

Soderberg, K., Good, S.P., O'Connor, M., Wang, L., Ryan, K., Caylor, K.K., 2013. Using atmospheric trajectories to model the isotopic composition of rainfall in central Kenya. Ecosphere 4 (3), 33. http://dx.doi.org/10.1890/ES12-00160.1.

Speed, M., Tezlaff, D., Soulsby, C., Hrachowitz, M., Waldron, S., 2010. Isotopic and geochemical tracers reveal similarities in transit times in contrasting mesoscale catchments. Hydrol. Process. 24, 1211-1224. http://dx.doi.org/10.1002/ hyp.7593.

Sturm, C., Zhang, Q., Noone, D., 2010. An introduction to stable water isotopes in climate models: benefits of forward proxy modelling for paleoclimatology. Clim. past 6, 115-129. http://dx.doi.org/10.5194/cp-6-115-2010.

Su, L., Yuan, Z., Fung, J.C.H., Lau, A.K.H., 2015. A comparison of HYSPLIT backward trajectories generated from two GDAS datasets. Sci. total Environ. 506-507, 527-537.

Tezlaff, D., Soulsby, C., 2008. Towards simple approaches for mean residence time estimation in ungauged basins using tracers and soil distributions. J. Hydrology 363, 60-74. http://dx.doi.org/10.1016/j.jhydrol.2008.10.001.

Tremoy, G., Vimeux, F., Mayaki, S., Souley, I., Cattani, O., Risi, C., Favreau, G., Oï, M., 2012. A 1-year long 180 record of water vapor in Niamey (Niger) reveals insightful atmospheric processes at different timescales. Geophys. Res. Lett. 39, L08805. http://dx.doi.org/10.1029/2012GL051298.

Tremoy, G., Vimeux, F., Soumana, S., Souley, I., Risi, C., Favreau, G., Oï, M., 2014. Clustering mesoscale convective systems with laser-based water vapor 180 monitoring in Niamey (Niger). J. Geophys. Res. 119 http://dx.doi.org/10.1002/ 2013JD020968, 5079-5013.

Ulloa, A., Aguilar, T., Goicoechea, C., Ramírez, R., 2011. Description, classification, and geological aspects of the karstic regions of Costa Rica. Geol. J. Central Am. 45, 53-74.

Vimeux, F., Gallaire, R., Bony, S., Hoffmann, G., Chiang, J.C.H., 2005. What are the climate controls on $\mathrm{dD}$ in precipitation in the Zongo Valley (Bolivia)? Implications for the Illimani ice core interpretation. Earth Planet. Sci. Lett. 240 (2005), 205-220.

Vuille, M., Wermer, M., 2005. Stable isotopes in precipitation recording South American summer monsoon and ENSO variability: observations and model results. Clim. Dyn. 25, 401-413. http://dx.doi.org/10.1007/s00382-005-0049-9.

Vuille, M., Bradley, R.S., Keimig, F., 2000a. Interannual climate variability in the Central Andes and its relation to tropical Pacific and Atlantic forcing. J. Geophys. Res. 105, 12447-12460.

Vuille, M., Bradley, R.S., Keimig, F., 2000b. Climatic variability in the Andes of Ecuador and its relation to tropical Pacific and Atlantic sea surface temperature anomalies. Climate 13, 2520-2535.

Vuille, M., Bradley, R.S., Healy, R., Werner, M., Hardy, D.R., Thompson, L.G., Keimig, F., 2003. Modeling d180 in precipitation over the tropical Americas 2: simulation of the stable isotope signal in Andean ice cores. J. Geophys. Res. 108 http:// dx.doi.org/10.1029/2001JD002039.

Wassenaar, L.I., Athanasopoulos, P., Hendry, M.J., 2011. Isotope hydrology of precipitation, surface and ground waters in the Okanagan Valley, British Columbia, Canada. J. Hydrol. 411, 37-48. http://dx.doi.org/10.1016/j.jhydrol.2011.09.032.

Waylen, M.E., 1996. Interannual variability of monthly precipitation in Costa Rica. J. Clim. 9, 2606-2613.

Wen, X.F., Sun, X.M., Zhang, S.C., Yu, G.R., Sargent, S.D., Lee, X., 2008. Continuous measurement of water vapor $\mathrm{D} / \mathrm{H}$ and $180 / 160$ isotope ratios in the atmosphere. J. Hydrol. 349, 489-500. http://dx.doi.org/10.1016/j.jhydrol.2007.11.021.

Wu, J., Ding, Y., Ye, B., Yang, Q., Zhang, X., Wang, J., 2010. Spatio-temporal variation of stable isotopes in precipitation in the Heihe River Basin, Northwestern China. Environ. Earth Sci. 61, 1123-1134.

Wu, H., Zhang, X., Xiaoyan, L., Li, G., Huang, Y., 2015. Seasonal variations of deuterium and oxygen-18 isotopes and their response to moisture source for precipitation events in the subtropical monsoon region. Hydrol. Process. 29, 90-102. 